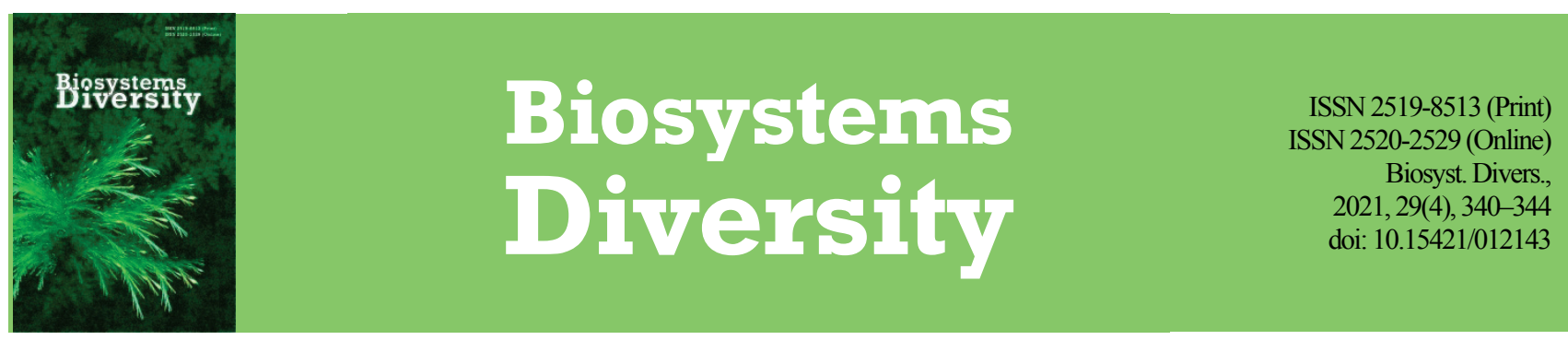

\title{
Endoparasitoses of the Eurasian collared dove (Streptopelia decaocto) on the northern Black Sea coast of Ukraine
}

\author{
M. Bogach*, A. Paliy*, P. Liulin**, O. Bohach*, A. Palii*** \\ *Institute of Experimental and Clinical Veterinary Medicine, Kharkiv, Ukraine \\ **Kharkiv State Zooveterinary Academy, Malaya Danilovka, Ukraine \\ ***Kharkiv Petro Vasylenko National Technical University of Agriculture, Kharkiv, Ukraine
}

Article info

Received 29.09.2021

Received in revised form 23.10.2021

Accepted 24.10.2021

Institute of Experimental and

Clinical Veterinary Medicine

Pushkinska st., 83, Kharkiv, 61023

Ukraine. Tel.: +38-067-997-49-25

E-mail:bogach_n@ukr.net

Kharkiv State Zooveterinary

Academy, Akademichna st., 1 ,

Malaya Danilovka

Kharkiv region, 62341, Ukraine.

Tel.: +38-097-148-40-02.

E-mail:liulinpetr@gmail.com

Kharkiv Petro Vasylenko National

Technical University of Agriculture,

Alcherskyh st., 44, Kharkiv, 61002,

Ukraine. Tel.: +38-063-712-82-42.

E-mail:paliy.andriy@ukr.net

\author{
Bogach, M., Paliy, A., Liulin, P., Bohach, O., \& Palii, A. (2021). Endoparasitoses of the Eurasian collared dove (Streptopelia \\ decaocto) on the northern Black Sea coast of Ukraine. Biosystems Diversity, 29(4), 340-344. doi:10.15421/012143
}

One of the main tasks of ecological parasitology at the present stage is to determine patterns of spread of invasive diseases of poultry in the environment through a thorough epidemiological examination, as well as to determine the main directions and factors of spread of parasites in Ukraine. Some pigeon health problems can affect their populations, but parasitic infections play an important role. Our research found that $83.3 \%$ of Eurasian collared doves examined (Streptopelia decaocto) were affected by endoparasites. The commonest helminths were Raillietina spp. with the average invasion intensity of $4.9 \pm 1.3$ specimens/ind., Baruscapillaria spp. and Ascaridia columbae with an invasion intensity of $4.6 \pm 1.5$ and $3.7 \pm 2.1$ specimens/ind., respectively. The commonest cestodes were Raillietina spp. with the extent of invasion of 52.2\% and Davainea proglottina $-6.7 \%$. The Amoebotaenia cuneata cestodes were recorded in $3(3.3 \%)$ doves, and Echinolepis carioca - only in $2(2.2 \%)$ doves. Six doves $(6.7 \%)$ were infected with the nematode Ascaridia columbae and $5(5.6 \%)$ - Baruscapillaria spp. Eimerian oocysts were found in $9(10 \%)$ collared doves, and Trichomonas gallinae was recorded in $15(16.7 \%)$ birds. According to the results of helminthological autopsy and identification of the isolated pathogens, 8 varieties of mixinvasions were identified. In association with the Rayetins, there were the protozoa Eimeria spp. and Trichomonas gallinae and the nematode Ascaridia columbae. Two-component invasions were registered in $78.6 \%$ of doves, three-component infestations in $14.3 \%$ and four-component infestations in $7.1 \%$ of birds. Mixed infection with Raillietina spp. + Ascaridia columbae was found in the small intestine of Streptopelia decaocto, which was also pathomorphologically observed to have catarrhal-hemorrhagic enteritis, which was accompanied by the formation of a large number of spotted hemorrhages on the mucous membrane, and in the places of attachment of cestodes - necrotic-caseous areas. Temperature and other weather conditions such as humidity, precipitation, etc. of the northern Black Sea coast affect the population size of intermediate host cestodes. Continuous monitoring of invasive diseases of pigeons of different species will help to take the necessary preventive measures against endoparasitoses of birds.

Keywords: pigeons; cestodes; nematodes; eimeriosis; trichomonosis; distribution; epidemiology.

\section{Introduction}

Pigeons of the genus Columbiformes are birds that can be found almost all over the world. Those who observe these birds cannot even imagine how harmful their disorderly reproduction can be and how many risks they are exposed to. They are the main source of a number of infections and pathogens (Bled et al., 2011; Orlova \& Orlov, 2019). The Eurasian collared dove Streptopelia decaocto Frivaldszky (1838) (Columbiformes: Columbidae) is a common resident bird in many countries, mainly in villages and cities (Dinevich et al., 2003; Scheidt \& Hurlbert, 2014; Bagi et al., 2018). Cities and suburbs are home to a large number of pigeons of various breeds, including wild pigeons, which are permanent residents of parks, playgrounds, markets and other facilities and can serve as distributors of the commonest intestinal nematodes (Vaz et al., 2017; El-Dakhly et al., 2019). Streptopelia decaocto, since the 1930s, has spread from West Asia and the Balkans to all of Europe and Central Asia, and continues to expand its range. The first birds in Ukraine appeared in Uzhgorod in 1944. Three years later it was already nesting in Mukachevo and Chop. Soon it flew through the Carpathian Mountains to Lviv region. Then it gradually inhabited Volyn, Rivne, Zhytomyr. In 1955, this species was first observed in Kyiv, in 1960 - in Sumy. Then there was the settlement of Southern Ukraine. Currently, the Eurasian collared dove is a common species in Ukraine. It lives exclusively in settlements - both in small villages and large cities. It inhabits areas with well-developed woody vegetation. It nests more often in old parks, cemeteries, areas of old residential buildings with courtyards, street avenues. In summer and autumn, it occurs in agricultural lands (Talposh, 2019). On the territory of Kharkiv, absolute surveys of the Eurasian collared dove with mapping elements in squares with an area of $0.25 \mathrm{~km}^{2}$ were conducted ( 40 squares were surveyed). Then the number of collared doves in the following habitats was determined by extrapolation: multi-storey buildings, private buildings, industrial zone, forest zone, park zone, wastelands (including undeveloped areas, etc.). The average nesting density of the species within the city of Kharkiv was 6 pairs $/ \mathrm{km}^{2}$ in the zone of private development, 4.6 pairs $/ \mathrm{km}^{2}$ - in areas with multi-storey buildings, 3 pairs $/ \mathrm{km}^{2}$ - in the industrial zone, 2 pairs $/ \mathrm{km}^{2}$ - in the park zone, 0.4 pairs $/ \mathrm{km}^{2}$ - in wastelands and other undeveloped areas. The estimate of the size of the nesting population of the collared dove, taking into account the areas of these habitats within the city, was slightly more than 850 pairs (Brezgunova et al., 2017).

The Eurasian collared dove is considered a pest of crops, as it usually feeds on large flocks, grains, fruits and can spoil them. It also feeds on beetles and butterflies (Olimpi et al., 2020). This species hosts a large number of endoparasites, such as cestodes, nematodes and unicellular protozoa (Mushi et al., 2000; Senlik et al., 2005).

One of the main tasks of ecological parasitology at the present stage is to establish patterns of spread of invasive diseases of poultry in the environment through careful epizootological examination, as well as to determine the main directions and factors of parasitism in Ukraine (Nakao et al., 2019; Paliy et al., 2020). Researchers believe that intestinal parasito- 
sis is primarily a sanitary problem, and its prevention should be based on sanitary-parasitological monitoring (Harlin \& Wade, 2009; Ahmed et al., 2017). Some health problems of doves can affect their populations, but parasitic infections play an important role (Mohammed et al., 2019).

However, there are no data on the prevalence of $S$. decaocto parasites on the northern Black Sea coast of Ukraine. The population of wild pigeons is growing every year. They infect private poultry, thus spreading the invasion to synanthropic and domestic pigeons. Therefore, finding out the spread of parasitic diseases will help prevent the infection of the population of domestic and wild pigeons in the region.

\section{Materials and methods}

The research was conducted in the period from August to November 2019 and 2021 on the northern Black Sea coast of Ukraine (Odessa, Mykolaiv, Kherson regions). A total of $90 \mathrm{~S}$. decaocto individuals seized during sport hunting were studied: 30 in Berezivsky, Odesa and BelgorodDnistovsky districts of Odessa region, 30 in Bashtansky and Mykolayiv districts of Mykolayiv region, 30 in Skadovsk and Kherson districts of Kherson region. The experiments performed on the animals did not contradict the current legislation of Ukraine (Article 26 of the Law of Ukraine 5456-VI of 16.10.2012 "On protection of animals from cruel treatment"), adopted by the First National Congress of Bioethics (Kyiv, 2001) and international bioethical standards (materials of the IV European Convention for the Protection of Vertebrate Animals Used for Experimental and Other Purposes, Strasbourg, 1985) (Simmonds, 2018; Kabene \& Baadel, 2019). The research program was reviewed and approved by the Bioethics Commission of the National Research Center the Institute of Experimental and Clinical Veterinary Medicine.

To diagnose trichomonosis of pigeons, fresh wet smears were taken from the mucous membrane of the oral cavity and throats of the birds, which were examined in the laboratory of epizootology and parasitology of the Odessa research station NSC "IEKVM" by staining according to the method of Romanowsky-Giemsa using light microscope $\times 400$ (Anderson et al., 2009). Trichomonas was identified by signs of mobility and the presence of flagella (Dovc et al., 2004).

Species of helminths were identified morphologically - nematodes were identified after clearing in lactic acid with glycerin, and cestodes after staining with lactic acid carmine. Differentiation of cestode oncospheres (raietin, davenii) was performed by staining eggs with diamond green in the dilution of 1:10,000 and then the capsules were examined in Petri dishes. Oncospheres of Davainea proglottina were stained with light green in 3-5 minutes, and oncospheres of Raillietina spp. during this time were not stained (Ukrainian patent for utility model No. 78451).

To diagnose eimeriosis, pigeon feces were examined by the standardized Fuleborn method. Microscopic examinations were performed at low magnification of the microscope $(8 \times 10)$ with subsequent determination of the average rates of invasion extent (EI, \%) and invasion intensity (II, the number of oocysts in $1 \mathrm{~g}$ of feces) (Bakulin, 2006).

\section{Results}

Both helminths of the classes of cestodes and nematodes, and protozoa, were recorded in the intestinal canal of the collared dove. It was found that $83.3 \%$ of the examined collared doves $S$. decaocto were infected by endoparasites. The commonest of the cestodes were Raillietina spp. (Molin, 1858; Megnin, 1880) with the invasion extent of $52.2 \%$ and Davainea proglottina (Davainea, 1860) - 6.7\%. The cestode Amoebotaenia cuneata (von Linstow, 1872) was recorded in 3 doves with the invasion extent of $3.3 \%$, and Echinolepis carioca (Magalhaes, 1898) in only $2(2.2 \%)$ doves. According to the results of research, 6 doves $(6.7 \%)$ were infected with the nematode Ascaridia columbae (Gmelin, 1979) and 5 (5.6\%) doves Baruscapillaria spp. (Madsen, 1945; Moravec, 1982). Eimeriosis oocysts of Eimeria columbarum (Nieschulz, 1935), E. labbeana (Labbe, 1896; Pinto, 1928), E. columba (Mitra and Das Gupta, 1937) were found in 9 (10\%) doves, and Trichomonas gallinae (Rivolta, 1878) was recorded in $15(16.7 \%)$.

The commonest helminths of Raillietina spp. were detected by pathological autopsy in the intestines of birds, with the average invasion intensi- ty of $4.9 \pm 1.3$ specimens/ind., Baruscapillaria spp. and Ascaridia columbae with the invasion intensity of $4.6 \pm 1.5$ specimens/ind. and $3.7 \pm 2.1$ specimens/ind., respectively (Table 1).

Table 1

Intensity of infection with endoparasites

of the collared dove Streptopelia decaocto $(\mathrm{x} \pm \mathrm{SE}, \mathrm{n}=90)$

\begin{tabular}{lccc}
\hline \multicolumn{1}{c}{ Parasite } & $\begin{array}{c}\text { Helminthes detected, } \\
\text { specimens }\end{array}$ & $\begin{array}{c}\text { Invasion intensity, } \\
\text { specimens / ind. }\end{array}$ & Min-max \\
\hline Raillietina spp. & 234 & $4.9 \pm 1.3$ & $1-5$ \\
Davainea proglottina & 18 & $3.0 \pm 0.9$ & $1-3$ \\
Echinolepis carioca & 3 & $1.5 \pm 0,2$ & $1-2$ \\
Amoebotaenia cuneata & 17 & $5.7 \pm 0.2$ & $2-4$ \\
Ascaridia columbae & 22 & $3.7 \pm 2.1$ & $1-4$ \\
Baruscapillaria spp. & 23 & $4.6 \pm 1.5$ & $3-6$ \\
Eimeria spp. & - & $227.5 \pm 22.1^{*}$ & $175-281$ \\
Trichomonas gallina & - & $12.6 \pm 0.2^{* *}$ & $9-16$ \\
\hline
\end{tabular}

Note: * - oocystes in $1 \mathrm{~g}$ of feces; ** - trichomonosis in the field of view of the microscope.

The pathological changes of eimeriosis in the doves were characterized by slightly disheveled dull feathers, and the back of the body around the cloaca was contaminated with fecal masses. The goiter was halfempty, and the muscular stomach contained the residuals of a small amount of fodder. The intestine retained its characteristic tubular shape, the walls of the duodenum and jejunum were thickened in places, the lumen of the intestine was uneven, narrowed in some areas, without feed content (empty). The cecum had a normal shape and volume, greyish on the outside, the relief of their mucous membrane was partially smoothed. The rectum was balloon-like dilated, with much thinner walls, contained semi-liquid watery, poorly formed fecal masses in the lumen. The intensity of lesions was from 175 to 281 oocysts in $1 \mathrm{~g}$ of feces (Fig. 1).

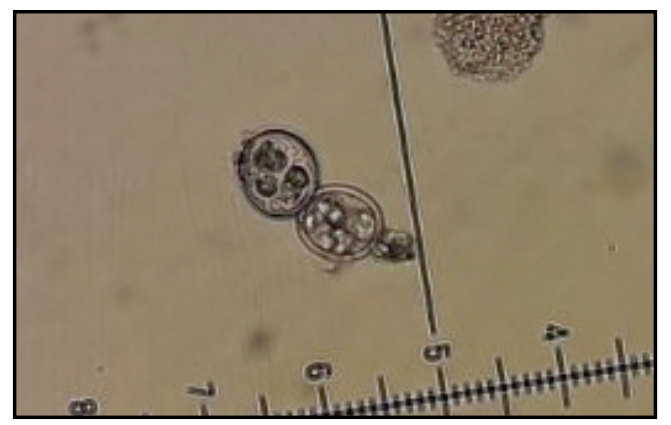

Fig. 1. Oocystes Eimeria spp. in S. decaocto

In the fecal masses of infested collared doves in the field of view of the microscope single eggs of Baruscapillaria spp. were recorded, although the intensity of the invasion was high (Fig. 2).

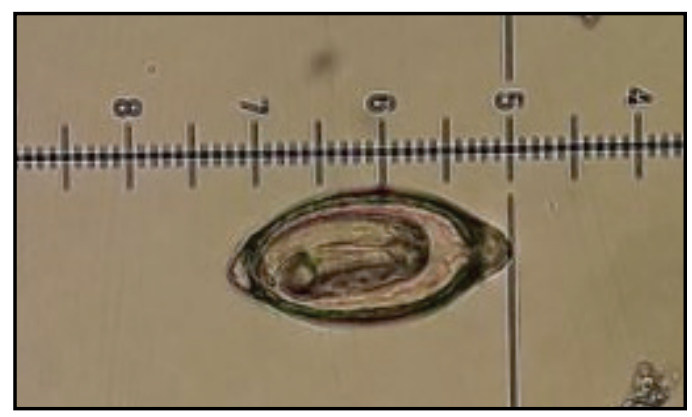

Fig. 2. Egg Baruscapillaria spp. in S. decaocto

One dove from Skadovsk district of Kherson region and another from Belgorod-Dniester district of Odessa region had a high degree of intensity of Raillietina spp. and Ascaridia columbae (Figs. 3, 4). According to the results of helminthological autopsies of the doves, it was found that monoinvasion was more often recorded in the collared dove (EI - 67.8\%; $81.3 \%$ - from sick doves). Mixed invasions were less frequently recorded (EI-15.6\%; 18.7\% - of infected doves). 


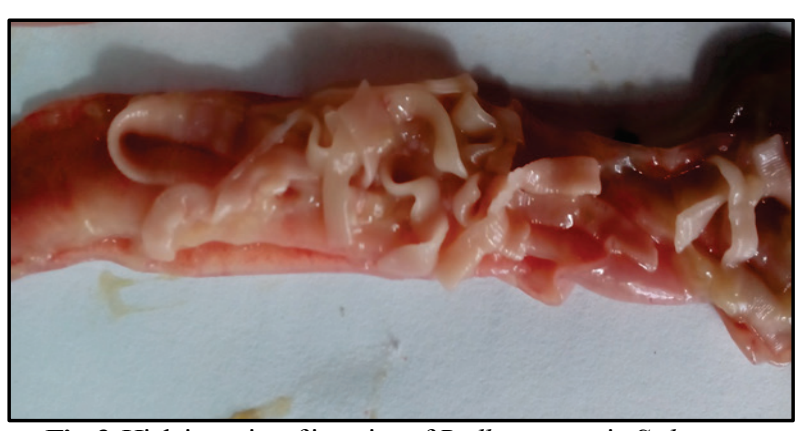

Fig. 3. High intensity of invasion of Raillietina spp. in S. decaocto

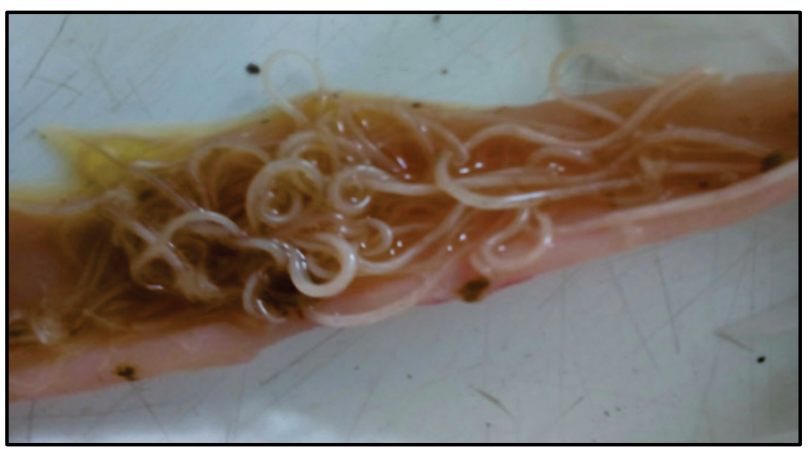

Fig. 4. High intensity of invasion of Ascaridia columbae in $S$. decaocto

Two-component parasitocenoses (EI - 12.2\%; 78.6\% - of examined doves with mixed infections) were recorded mostly, where raietins were the main component of the parasite association. A smaller percentage of mixed infestations was seen, which consisted of three components (EI $2.2 \% ; 14.3 \%$ - of examined doves with mixed infections) and four (EI$1.1 \% ; 7.1 \%$ - of examined doves with mixed infections).

In the collared dove in the northern Black Sea region, 8 combinations of pathogens of mixed invasions were found, in which the main comember was raietins (Table 2).

Table 2

Distribution of mono- and mixed invasion in the collared dove Streptopelia decaocto in the northern Black Sea region

\begin{tabular}{|c|c|c|c|}
\hline $\begin{array}{l}\text { Type of } \\
\text { invasion }\end{array}$ & Association of parasites & $\begin{array}{l}\text { Helminths } \\
\text { detected, } \\
\text { specimens }\end{array}$ & $\begin{array}{l}\mathrm{EI}, \% \\
(\mathrm{n}=90)\end{array}$ \\
\hline \multirow{9}{*}{$\begin{array}{l}\text { One- } \\
\text { components }\end{array}$} & Raillietina spp. & 33 & \multirow{9}{*}{67.8} \\
\hline & Davainea proglottina & 4 & \\
\hline & Echinolepis carioca & 1 & \\
\hline & Amoebotaenia cuneata & 3 & \\
\hline & Ascaridia columbae & 3 & \\
\hline & Baruscapillaria spp. & 3 & \\
\hline & Eimeria spp. (oocysts) & 5 & \\
\hline & Trichomonas gallinae (protozoan) & 9 & \\
\hline & Total & 61 & \\
\hline \multirow{6}{*}{$\begin{array}{l}\text { Two- } \\
\text { components }\end{array}$} & Raillietina spp. + Davainea proglottina & 1 & \multirow{6}{*}{12.2} \\
\hline & Raillietina spp. + Ascaridia columbae & 2 & \\
\hline & Raillietina spp. + Baruscapillaria spp. & 1 & \\
\hline & Raillietina spp. + Eimeria spp. & 3 & \\
\hline & Raillietina spp. + Trichomonas gallinae & 4 & \\
\hline & Total & 11 & \\
\hline \multirow{3}{*}{$\begin{array}{l}\text { Three- } \\
\text { components }\end{array}$} & $\begin{array}{l}\text { Raillietina spp. }+ \text { Echinolepis carioca }+ \\
\text { Trichomonas gallinae }\end{array}$ & 1 & \multirow{3}{*}{2.2} \\
\hline & $\begin{array}{l}\text { Raillietina spp. }+ \text { Ascaridia columbae }+ \\
\text { Eimeria spp. }\end{array}$ & 1 & \\
\hline & Total & 2 & \\
\hline \multirow[t]{2}{*}{$\begin{array}{c}\text { Four- } \\
\text { components }\end{array}$} & $\begin{array}{l}\text { Raillietina spp. }+ \text { Davainea proglottina }+ \\
\text { Baruscapillaria spp. }+ \text { Trichomonas } \\
\text { gallinae }\end{array}$ & 1 & \multirow[t]{2}{*}{1.1} \\
\hline & Total & 1 & \\
\hline & Total parasitocenoses & 75 & 83.3 \\
\hline
\end{tabular}

Raillietina spp. (EI - 44\%) and Trichomonas gallinae (EI - 12\%) were most often recorded as monoinvasion. Eimeria spp. was diagnosed in $6.7 \%$ of infected doves, and Davainea proglottina in $5.4 \%$ of birds.
Only in three pigeons (4\%) did we record Amoebotaenia cuneata, Ascaridia columbae and Baruscapillaria spp. and one collared dove (1.3\%) was found to have the cestode Echinolepis carioca.

Of the two-component mixed invasions, Raillietina spp. + Trichomonas gallinae (EI-5.4\%), Raillietina spp. + eimeriosis (EI-4.0\%), Raillietina spp. + Ascaridia columbae (EI - 2.7\%) were diagnosed most often. Less common were Raillietina spp. + Davainea proglottina and Raillietina spp. + Baruscapillaria spp. (EI-1.3\%).

Of the three-component and four-component, Raillietina spp. + Echinolepis carioca + Trichomonas gallinae, Raillietina spp. + Ascaridia columbae + Eimeria spp. and Raillietina spp. + Davainea proglottina + Baruscapillaria spp. + Trichomonas gallinae were recorded(EI-1.3\%).

Raillietina spp. was registered at pathological autopsy of $S$. decaocto (Fig. 5). Pathological changes were characterized by serous-catarrhal enteritis, the signs of which were most pronounced in the places of fixation of cestodes. The mucous membrane of the small intestine was covered with numerous small erosions and spot hemorrhages.

Pathomorphologically, in mixed invasion of Raillietina spp. + Ascaridia columbae in the small intestine of $S$. decaocto, we observed catarrhal-hemorrhagic enteritis, which was accompanied by the formation of a large number of spotted hemorrhages on the mucous membrane, and necrotic-caseous areas in the places of attachment of cestodes (Fig. 6).

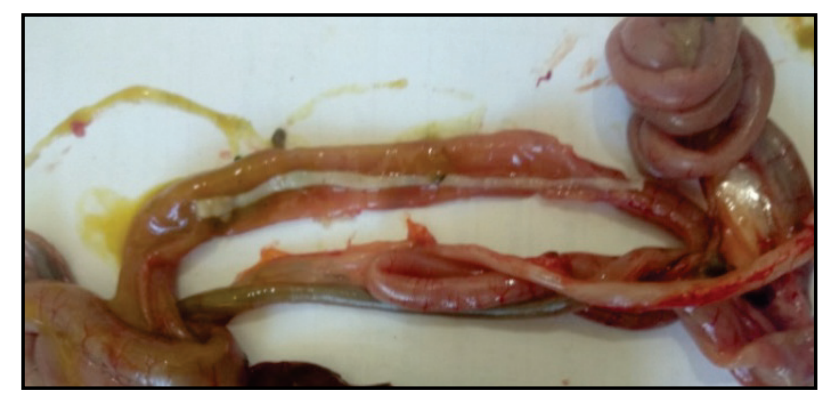

Fig. 5. Raillietina spp. in the small intestine of S. decaocto

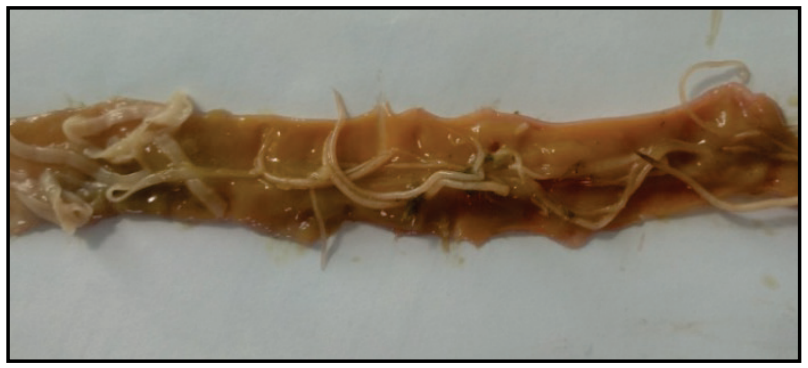

Fig. 6. Raillietina spp. + Ascaridia columbae in the small intestine of $S$. decaocto

\section{Discussion}

According to the results of our research, it is necessary to conduct additional research on the northern Black Sea coast of Ukraine on pigeons of different species and especially the collared dove, which makes dispersive movements and at the same time settles near towns and villages and comes into contact with other poultry species - chickens, turkeys and domestic pigeons.

The operation of agricultural enterprises is accompanied by feeding of wild birds, a large number of which can lead to significant economic losses and pose epizootiological threats (Chaplygina et al., 2019; Ferenczi et al., 2021; Velkers et al., 2021). The commonest of these bird species are pigeons (Ellakany et al., 2019; Giunchi et al., 2020). For any effective program to control endo- and ectoparasitoses of poultry, the collared dove should be prevented from approaching poultry houses, as they can share watering and feeding sites and be carriers of various diseases (Lucas et al., 2008; Mugale et al., 2015).

Almost all birds are infested with various types of endoparasites, both in the form of mono- and mixed invasion. The endoparasites recorded in our studies are of great veterinary importance and therefore require de- 
tailed study (Al-Quraishy et al., 2021). The high prevalence of monoinvasion in doves, compared to double and triple infections, leads to competition in which nutrients are shared by endoparasites and leads to the development of mono- or mixed invasions. This may also indicate an innate systemic strategy of endoparasites to avoid competition (Santos et al., 2020).

The prevalence of pigeon endoparasites was studied in the Canary Islands, where eimeria oocysts were recorded in $50 \%$, cestodes of the species Raillietina micracantha (Fuhrmann, 1909) López Neyra, 1947 - in $44 \%$ and Ascaridia columbae - in $40 \%$ of cases (Foronda et al., 2004). In the state of Minas Gerais in Southeastern Brazil, a study of wild feral pigeons (C. livia domestica) showed that all pigeons were infected with Eimeria spp. The causative agent of $A$. columbae was detected in $4.9 \%$ of pigeons, and in $3.2 \%$ - a mixed invasion caused by A. columbae and Raillietina spp. (Oliverra et al., 2000). In the Zaria region of northern Nigeria, pigeon infestation caused by a single pathogen was more common (37.5\%) than double $24(10.0 \%)$ and triple $(0.8 \%)$ (Adang et al., 2008). According to a number of researchers, in Central Ethiopia, a higher number of infected pigeons $-27 \%$ had a monoinvasion, compared with those who had a mixed invasion $-1 \%$ caused by $R$. echinobothrida + $R$. cesticillus and $1 \%$ R. echinobothrida + R. tetragona in absence of triple infection (Ashenafi \& Eshutu, 2004)

Among pigeon nematodes, ascariasis is one of the most frequently reported infestations (Bahrami et al., 2013). Gupta et al. (2011) indicate that pigeons may play the role of intermediate host for certain helminth species. Despite the widespread population of $S$. decaocto in Iraq, only a few relatively recent articles have been published on their parasites. AlBakry (2009) reported the simplest Trichomonas gallinae. In the survey of 250 - Columba oenas, $200-$ C. livia and $40-$ S. decaocto, the prevalence was $22.0 \%, 17.5 \%$ and $10.0 \%$, respectively. Mehmood et al. (2019) isolated cestodes: Aporina delafondi, Cotugnia digonopora, Raillietina echinobothrida, $R$. serrata and $R$. tetragona. The infestation of pigeons was $63 \%$ at the intensity of 5.3 specimens/bird.

In a study of wild pigeons in Santiago, Chile, Trichomonas gallinae was detected in $11 \%$ of cases without any clinical signs and pathological changes at autopsy. Seven species of nematodes were identified: Tetrameres spp. (14\%), Capillaria annulata (1\%), C. columbae (11\%), C. obsignata (1\%), Ascaridia columbae (5\%), Dispharynx spiralis (2\%) and Gongylonema ingluvicola (2\%). The Cestoda class found in a single pigeon was represented by Aporina delafondi (Toro et al., 1999). AlRammahi et al. (2013) reported the spread of protozoa Trichomonas spp. in $13.3 \%$ of pigeons and three species of cestodes: Raillietina spp. (64.2\%), Aporina spp. (18.6\%) and Cotugnia spp. (17.1\%). In a study of 63 Eurasian collared doves $S$. decaocto from Florida, nine species of helminths ( 5 nematodes, 2 cestodes and 2 trematodes) were identified. The most common were Ascaridia columbae (73.0\%) and Baruscapillaria obsignata (11.1\%) (Bean et al., 2005). The data from this study suggest that the environment in which doves live and the food search strategies of each host species are the driving force behind the helminth component communities.

In various studies, differences in the prevalence of endoparasitoses are predicted by many factors that influence the onset of the disease, such as host resistance to infestation, eating habits, climatic conditions, geographical differences, and living conditions. Adult birds can remain infected for a year or more and are a constant source of infection for their chicks (Radfar et al., 2012). Monitoring of invasive diseases of pigeons of different species will help the necessary preventive measures to be taken against endoparasitoses of birds (Boyko \& Brygadyrenko, 2019). Along with parasitic diseases, pigeon lesions and bacterial microflora are noted (Teske et al., 2013; Han et al., 2021).

Pigeons, due to their close interaction with humans and other domestic and wild birds, serve as a potential reservoir of zoonotic parasites (Adang et al., 2008). Both domestic and wild pigeons are not harmless birds, they can serve as hidden potential reservoirs of too many human diseases, and can transmit parasitic diseases to animals and poultry (Piasecki, 2006). The authors report that wild pigeons and domestic pigeons are usually infected by internal and external parasites through a common food source (Ali et al., 2020). Both domestic and wild pigeons feed mainly on grain, but consume beetles, snails, earthworms, and ants, which can be carriers of invasive stages of helminths (Boyko et al., 2009; Bogach et al., 2020). The prevalence and level of infestation of birds varies depending on the type of parasite, the physiological condition of the infested individual, as well as the geographical location of the natural and climatic zone (Oniye et al., 2000).

\section{Conclusion}

According to the results of helminthological dissections of the collared dove $S$. decaocto, raietinosis in the form of monoinvasion was recorded most often ( $44 \%$ of sick pigeons, EI - 36.7\%). Raietinosis was also recorded in mixed invasions (18.7\% of infected doves, EI - 15.6\%) with pathogens Trichomonas gallinae, Eimeria spp., Ascaridia columbae, Davainea proglottina and Baruscapillaria spp. Pathomorphological changes in the small intestine of $S$. decaocto were characterized by the development of catarrhal-hemorrhagic enteritis and dystrophic-necrotic changes in the liver, which occurred due to mechanical toxic and immunosuppressive action of cestodes.

\section{References}

Adang, K. L., Onie, S. J., Ajanusi, O. D., Ezilor, A. Y., \& Abdu, P. A. (2008). Gastrointestinal helminths of domestic pigeons (Columba livia domestica Gmelin, 1789 Aves: Columbidae) in Zaria, Northern Nigeria. Science World Journal, 3(1), 33-37.

Ahmed, H., Naz, M., Mustafa, I., Khan, M. R., Asif, S., Afzal, M. S., Arshad, M., Naveed, M., Ali, S., \& Simsek, S. (2017). Impact of epidemiological factors on the prevalence, intensity and distribution of ectoparasites in pigeons. Journal of Parasitic Diseases, 41(4), 1074-1081.

Al-Bakry, H. S. (2009). Prevalence of avian trichomoniasis in different species of pigeons in Mosul. Iraqi Journal of Veterinary Sciences, 23(2), 105-109.

Ali, M., Ibrahim, R., Alahmadi, S., \& Elshazly, H. (2020). Ectoparasites and intestinal helminths of pigeons in Medina, Saudi Arabia. The Journal of Parasitology, 106(6), 721-729.

Al-Quraishy, S., Abdel-Gaber, R., Dkhil, M. A., Abdel-Baki, A. S., Alotaibi, M., Alhafidh, W., \& Al-Houshany, N. (2021). Detection of Raillietina saudiae from the domestic pigeon in Saudi Arabia through 18S and 28S rDNA genes. Letters in Applied Microbiology, 72(1), 90-97.

Al-Rammahi, H. M., AL-Hasnawy, M. H., \& Abbas, A. K. (2013). Concurrent infection of cestodes with trichomoniasis in domestic and wild Columbides birds in Babylon province. The Iraqi Journal of Veterinary Medicine, 37(2), 192-198.

Anderson, N. L., Grahn, R. A., Van-Hoosear, K., \& Bondurant, R. H. (2009). Studies of trichomonal protozoa in free ranging songbirds: Prevalence of Trichomonas gallinae in house finches (Carpodacus mexicanus) and corvids and a novel trichomonad in mockingbirds (Mimus polyglottos). Veterinary Parasitology, 161, $178-186$.

Arfin, S., Sayeed, M. A., Sultana, S., Dash, A. K., \& Hossen, M. L. (2019). Prevalence of Trichomonas gallinae infection in pigeon of Jessore district, Bangladesh. Journal of Advanced Veterinary and Animal Research, 6(4), 549-552.

Ashenafi, H., \& Eshetu, Y. (2004). Study on gastro-intestinal helminths of local chickens in Central Ethiopia. Revue de Médecine Vétérinaire, 155(10), 504-507.

Bagi, Z., Dimopoulos, E. A., Loukovitis, D., Eraud, C., \& Kusza, S. (2018). MtDNA genetic diversity and structure of eurasian collared dove (Streptopelia decaocto). PloS One, 13(3), e0193935.

Bahrami, A. M., Hosseini, E., \& Razmjo, M. (2013). Important parasite in pigeon, its hematological parameter and pathology of intestine. World Applied Sciences Journal, 21(9), 1361-1365.

Bakulin, V. A. (2006). Bolezni ptits [Diseases of birds]. V. A. Bakulin, Saint Petersburg (in Russian).

Bean, D. L., Rojas-Flores, E., Foster, G. W., Kinsella, J. M., \& Forrester, D. J. (2005). Parasitic helminths of Eurasian collared-doves (Streptopelia decaocto) from Florida. The Journal of Parasitology, 91(1), 184-187.

Bled, F., Royle, J. A., \& Cam, E. (2011). Hierarchical modeling of an invasive spread: The Eurasian collared-dove Streptopelia decaocto in the United States. Ecological Applications, 21(1), 290-302.

Bogach, M. V., Paliy, A. P., Perots'ka, L. V., Pyvovarova, I. V., Stoyanova, V. Y., \& Palii, A. P. (2020). The influence of hydro-meteorological conditions on the spread of chicken cestodiasis. Regulatory Mechanisms in Biosystems, 11(3), 414418.

Boyko, A., Brygadyrenko, V., Shendryk, L., \& Loza, I. (2009). Estimation of the role of antropo-zoonosis invasion agents in the counteraction to bioterrorism. Counteraction to Chemical and Biological Terrorism in East European Countries. NATO Science for Peace and Security Series A: Chemistry and Biology. Springer Nature. Pp. 309-315. 
Boyko, O. O., \& Brygadyrenko, V. V. (2019). The impact of acids approved for use in foods on the vitality of Haemonchus contortus and Strongyloides papillosus (Nematoda) larvae. Helminthologia, 56(3), 202-210.

Brezgunova, O. O., Litinskiy, M. S., Litinska, Y. V., \& Sinna, O. I. (2017). Raspredeleniye i chislennost' kol'chatoy gorlitsy (Streptopelia decaocto) v gnezdovoy period na territorii g. Khar'kova [The distribution and numbers of the collared doves (Streptopelia decaocto) during the nesting period in Kharkiv City]. The Transactions of the Azov-Black Sea Ornithological Station, 20, 187-199 (in Ukrainian).

Chaplygina, A. B., Pakhomov, O. Y., \& Brygadyrenko, V. V. (2019). Trophic links of the song thrush (Turdus philomelos) in transformed forest ecosystems of North-Eastern Ukraine. Biosystems Diversity, 27(1), 51-55.

Dinevich, L., Matsyura, A., \& Leshem, Y. (2003). Temporal characteristics of night bird migration above Central Israel - A radar study. Acta Ornithologica, 38(2), $103-110$.

Dovc, A., Zorman-Rojs, O., Vergles-Rataj, A., Bole-Hribovsek, V., Krapez, U., \& Dobeic, M. (2004). Health status of free-living pigeons (Columba livia domesti$c a$ ) in the city of Ljubljana. Acta Veterinaria Hungarica, 52(2), 219-226.

El-Dakhly, K. M., El-Seify, M. A., Mohammed, E. S., Elshahawy, I. S., Fawy, S. A., \& Omar, M. A. (2019). Prevalence and distribution pattern of intestinal helminths in chicken and pigeons in Aswan, Upper Egypt. Tropical Animal Health and Production, 51(3), 713-718.

Ellakany, H. F., Elbestawy, A. R., Abd El-Hamid, H. S., Zedan, R. E., Gado, A. R. Taha, A. E., Soliman, M. A., Abd El-Hack, M. E., Swelum, A. A., Saadeldin, I. M., Ba-Awadh, H., \& Hussein, E. (2019). Role of pigeons in the transmission of avian avulavirus (Newcastle disease-genotype VIId) to chickens. Animals, 9(6), 338 .

Ferenczi, M., Beckmann, C., \& Klaassen, M. (2021). Rainfall driven and wild-bird mediated avian influenza virus outbreaks in Australian poultry. BMC Veterinary Research, 17(1), 306.

Foronda, P., Valladares, B., River-Medina, J. A., Figueruelo, E., Abreu, N., \& Casanova, J. C. (2004). Parasites of Columba livia (Aves: Columbiformes) in Tenerife (Canary Islands) and their role in the conservation biology of the Laurel pigeons. Parasitology, 1, 311-316.

Giunchi, D., Mucci, N., Bigi, D., Mengoni, C., \& Baldaccini, N. E. (2020). Feral pigeon populations: Their gene pool and links with local domestic breeds. Zoology, $142,125817$.

Gupta, D. K., Jahan, N., \& Gupta, N. (2011). Distribution pattern of apicomplexan parasites (Sporozoa: Haemosporida) in Columba livia, Gmelin. Journal of Parasitic Diseases, 35(1), 18-22.

Han, L., Lu, X. Q., Liu, X. W., Liao, M. N., Sun, R. Y., Xie, Y., Liao, X. P., Liu, Y.H., Sun, J., \& Zhang, R. M. (2021). Molecular epidemiology of fosfomycin resistant $E$. coli from a pigeon farm in China. Antibiotics, 10(7), 777.

Harlin, R., \& Wade, L. (2009). Bacterial and parasitic diseases of Columbiformes. Exotic Animal Practice, 12(3), 453-473.

Jiang, X., Sun, J., Wang, F., Li, H., \& Zhao, X. (2016). Prevalence of Trichomonas spp. in domestic pigeons in Shandong province, China, and genotyping by restriction fragment length polymorphism. The Veterinary Joumal, 211, 88-93.

Kabene, S., \& Baadel, S. (2019). Bioethics: A look at animal testing in medicine and cosmetics in the UK. Journal of Medical Ethics and History of Medicine, 12, 15.

Lucas, K. A., Sonnie, J. O., Augustine, U. E., Paul, A. A., Joseph, O. A., \& Kennedy, P. Y. (2008). Ectoparasites of the laughing dove Streptopelia senegalensis (Linnaeus, 1766) (Aves: Columbidae) in Zaria, Nigeria. Lundiana, 9(1), 67-71.

Mehmood, S., Nashiruddullah, N., Ahmed, J. A., \& Borkataki, S. (2019). Parasitic affections of domesticated pigeons (Columba livia) in Jammu, India. Annals of Parasitology, 65(1), 53-64.

Mohammed, B. R., Simon, M. K., Agbede, R. I. S., \& Arzai, A. H. (2019). Prevalence of intestinal helminth parasites of pigeons (Columba livia domestica Gmelin 1789) in Kano State, North-Western Nigeria. Veterinary Parasitology, Regional Studies and Reports, 16, 100289.

Mugale, M., Bhat, A. A., Gavhane, D. S., \& Bhat, S. A. (2015). Outbreaks of thrush in pigeons in Punjab state of India. Comparative Clinical Pathology, 24(3), 635-638.

Mushi, E. Z., Binta, M. G., Chabo, R. G., Ndebele, R., \& Panzirah, R. (2000). Parasites of domestic pigeons (Columba livia domestica) in Sebele, Gaborone, Botswana. Journal of the South African Veterinary Association,71(4), 249-250.
Nakao, M., Sasaki, M., Waki, T., Iwaki, T., Morii, Y., Yanagida, K., Watanabe, M. Tsuchitani, Y., Saito, T., \& Asakawa, M. (2019). Distribution records of three species of Leucochloridium (Trematoda: Leucochloridiidae) in Japan, with comments on their microtaxonomy and ecology. Parasitology International, 72, 101936

Olimpi, E. M., Garcia, K., Gonthier, D. J., De Master, K. T., Echeverri, A., Kremen, C., Sciligo, A. R., Snyder, W. E., Wilson-Rankin, E. E., \& Karp, D. S. (2020). Shifts in species interactions and farming contexts mediate net effects of birds in agroecosystems. Ecological Applications, 30(5), e02115.

Oliveira, P. R., Mundim, M. J. S., Cabral, D. D., Ribeiro, S. C., \& Rosa, G. N. (2000). Levantamento da fauna parasitaria das pombas domésticas (Columba livia domestica) de Uberlândia, MG, Brasil. Veterinaria Noticias, 6(2), 53-56.

Oniye, S. J., Audu, P. A., Adebote, D. A., Kwaghe, B. B., Ajanusi, O. J., \& Nfor, M. B. (2000). Survey of helminth parasites of laughing dove (Streptopelia segalensis) in Zaria, Nigeria. African Journal of Natural Sciences, 4, 65-66.

Orlova, M. V., \& Orlov, O. L. (2019). Conservation of animals' parasite species: Problems and prospects. Nature Conservation Research, 4(1), 1-21.

Paliy, A. P., Sumakova, N. V., Petrov, R. V., Berezovskiy, A. V., Risovaniy, V. I., Zon, G. A., Ivanovskaya, L. B., Fotin, A. I., Dolbanosova, R. V., Livoshchenko, L. P., Livoshchenko, Y. M., \& Palii, A. P. (2020). Endoparasic diseases of ostriches in Eastern Ukraine. Ukrainian Journal of Ecology, 10(4), 235-241.

Piasecki, T. (2006). Evaluation of urban pigeon (Columbia livia f. urbana) health status in relation to their threat to human's health. Medycyna Weterynaryjna, 62 $531-535$.

Radfar, M. H., Khedri, J., Adinehbeigi, K., Nabavi, R., \& Rahmani, K. (2012). Prevalence of parasites and associated risk factors in domestic pigeons (Columba livia domestica) and free-range backyard chickens of Sistan region, east of Iran. Journal of Parasitic Diseases, 36(2), 220-225.

Santos, H. M., Tsai, C. Y., Catulin, G. E. M., Trangia, K. C. G., Tayo, L. L., Liu, H. J., \& Chuang, K. P. (2020). Common bacterial, viral, and parasitic diseases in pigeons (Columba livia): A review of diagnostic and treatment strategies. Veterinary Microbiology, 247, 108779 .

Scheidt, S. N., \& Hurlbert, A. H. (2014). Range expansion and population dynamics of an invasive species: The Eurasian collared-dove (Streptopelia decaocto). PloS One, 9(10), e111510.

Senlik, B., Gulegen, E., \& Akyol, V. (2005). Effect of age, sex and season on the prevalence and intensity of helminth infections in domestic pigeons (Columba livia) from Bursa Province, Turkey. Acta Veterinaria Hungarica, 53, 449-456.

Simmonds, R. C. (2017). Chapter 4. Bioethics and animal use in programs of research, teaching, and testing. In: Weichbrod, R. H., Thompson, G. A. H., Norton, J. N. (Eds.). Management of animal care and use programs in research, education, and testing. 2nd edition. CRC Press, Taylor \& Francis, Boca Raton Pp. 1-28.

Stimmelmayr, R., Stefani, L. M., Thrall, M. A., Landers, K., Revan, F., Miller, A., Beckstead, R., \& Gerhold, R. (2012). Trichomonosis in free-ranging Eurasian collared doves (Streptopelia decaocto) and African collared dove hybrids (Streptopelia risoria) in the Caribbean and description of ITS-1 region genotypes. Avian Diseases, 56(2), 441-445.

Talposh, V. S. (2019). Kol'chataya gorlitsa Streptopelia decaocto na Ukraine [Collared dove Streptopelia decaocto in Ukraine]. Russian Omithological Journal, 28(1862), 5859-5866 (in Russian).

Teske, L., Ryll, M., Rubbenstroth, D., Hänel, I., Hartmann, M., Kreienbrock, L., \& Rautenschlein, S. (2013). Epidemiological investigations on the possible risk of distribution of zoonotic bacteria through apparently healthy homing pigeons. Avian Pathology, 42(5), 397-407

Toro, H., Saucedo, C., Borie, C., Gough, R. E., \& Alcaino, H. (1999). Health status of free-living pigeons in the city of Santiago. Avian Pathology, 6, 619-623.

Vaz, F. F., Silva, L. A. F. D., Ferreira, V. L., Silva, R. J. D., \& Raso, T. F. (2017). Gastrointestinal helminths of two populations of wild pigeons (Columba livia) in Brazil. Brazilian Journal of Veterinary Parasitology, 26(4), 446-450.

Velkers, F. C., Manders, T., Vernooij, J., Stahl, J., Slaterus, R., \& Stegeman, J. A (2021). Association of wild bird densities around poultry farms with the risk of highly pathogenic avian influenza virus subtype H5N8 outbreaks in the Netherlands, 2016. Transboundary and Emerging Diseases, 68(1), 76-87. 